\title{
An outlook on current legal status of the employees as the representatives of public authorities
}

Una perspectiva sobre el actual estatuto jurídico de los trabajadores como representantes de las autoridades públicas

\author{
Uma perspectiva sobre a situação legal atual dos funcionários como \\ representantes das autoridades públicas
}

\author{
Irina V. Aristova ${ }^{1}$ \\ Nelli Yu. Tsybulnyk ${ }^{2}$ \\ Viktoriia V. Horbonos ${ }^{3}$ \\ Serhii M. Melnyk ${ }^{4}$
}

Received: February $22^{\text {th }}, 2021$

Accepted: March 28 th, 2021

Published: July $6^{\text {th }}, 2021$

How to cite this article:

Irina V. Aristova, Nelli Yu. Tsybulnyk, Viktoriia V. Horbonos \& Serhii M. Melnyk. An outlook on current legal status of the employees as the representatives of public

authorities. DIXI, vol. 23, $\mathrm{n}^{\circ}$. 2, julio-diciembre 2021, 1-12.

DOI: https://doi.org/10.16925/2357-5891.2021.02.03

Research article. https://doi.org/10.16925/2357-5891.2021.02.03

1 Doctor of Laws, Professor, Head of the Department of Administrative and Information Law, Sumy National Agrarian University (Sumy, Ukraine).

E-mail: aristova07@gmail.com

ORCID: https://orcid.org/0000-0001-9211-3464

$2 \mathrm{PhD}$ in Law, Lecturer of the Department of Law-Enforcement Activity and Policeistics at Kharkiv National University of Internal Affairs (Kharkiv, Ukraine).

ORCID: https://orcid.org/0000-0002-5128-0511

3 Head of the Sector of International Cooperation, Department of Corporate Communications and Citizens' Appeals Processing, State Scientific Research Forensic Center of the MIA of Ukraine, Junior Lieutenant, Master of International Law.

ORCID: https://orcid.org/0000-0001-5825-5274

4 Doctor of Jurisprudence, Honored Educator of Ukraine, Head of the Military Law Institute Yaroslav Mudryi, National Law University (Kharkiv, Ukraine).

ORCID: https://orcid.org/0000-0002-3243-276X 


\section{Abstract}

The purpose of this article is to determine the features of the legal status of employees as representatives of public authorities, taking into account domestic and foreign experience. The main elements of the legal status of employees as representatives of public authorities in Ukraine are considered. It is noted that, as subjects of state power, employees are obliged to have a transparent, clear and unambiguous status in society. Among other things, they must comply in their direct activities with all the necessary norms and principles of domestic and international law, because the professional quality of their work will always be seen as a kind of external face of society. Attention is also focused on the fact that the efficiency of employees is directly related to the level of their self-organization, as well as a number of internal factors. In addition, it emphasizes the importance of civil servants, as well as persons working in public institutions and agencies of proper protection of the rights, freedoms and legitimate interests of men and citizens. Such a requirement for employees follows from the norms and principles of both domestic legislation (including the Basic Law of Ukraine and the Constitution of Ukraine) and international legal acts and declarations signed and ratified by Ukraine. Author's definitions of "legal status", "civil servant" as well as "public authority" are offered. Examples of successful experience of some developed, mostly Western, countries in building such conditions for the daily functioning of the state system and society as a whole, which managed to create a proper legal status of civil servants as public authorities, which would meet all important requirements today.

Keywords: Civil service, legislative consolidation, legal regulation, legal status, legal system, protection of rights and interests, public administration, public authority.

\section{Resumen}

El objetivo de este artículo es determinar las características del estatuto jurídico de los empleados como representantes de las autoridades públicas, teniendo en cuenta la experiencia nacional y extranjera. Se consideran los principales elementos del estatuto jurídico de los empleados como representantes de los poderes públicos en Ucrania. Se señala que, como sujetos del poder estatal, los empleados están obligados a tener un estatus transparente, claro e inequívoco en la sociedad. Entre otras cosas, deben cumplir en sus actividades directas con todas las normas y principios necesarios del derecho nacional e internacional, porque la calidad profesional de su trabajo siempre será vista como una especie de cara externa de la sociedad. También se presta atención al hecho de que la eficiencia de los empleados está directamente relacionada con el nivel de su autoorganización, así como con una serie de factores internos. Además, se hace hincapié en la importancia de los funcionarios, así como de las personas que trabajan en las instituciones y organismos públicos de la protección adecuada de los derechos, las libertades y los intereses legítimos de los hombres y los ciudadanos. Este requisito para los empleados se desprende de las normas y principios tanto de la legislación nacional (incluida la Ley Fundamental de Ucrania y la Constitución de Ucrania) como de los actos jurídicos internacionales y las declaraciones firmadas y ratificadas por Ucrania. El autor ofrece definiciones de "estatus legal", "funcionario" y "autoridad pública". Se presentan ejemplos de experiencias exitosas de algunos países desarrollados, en su mayoría occidentales, en la construcción de tales condiciones para el funcionamiento diario del sistema estatal y de la sociedad en su conjunto, que lograron crear un estatuto jurídico adecuado de los funcionarios como autoridades públicas, que cumpliría con todos los requisitos importantes en la actualidad.

Palabras clave: función pública, consolidación legislativa, regulación jurídica, estatuto jurídico, sistema jurídico, protección de derechos e intereses, administración pública, autoridad pública. 


\section{Resumo}

O objetivo deste artigo é determinar as características do status legal dos funcionários como representantes das autoridades públicas, levando em conta a experiência nacional e estrangeira. Os principais elementos do status legal dos funcionários como representantes das autoridades públicas na Ucrânia são considerados. Observa-se que, como sujeitos do poder estatal, os empregados são obrigados a ter um status transparente, claro e sem ambigüidade na sociedade. Entre outras coisas, eles devem cumprir em suas atividades diretas todas as normas e princípios necessários do direito interno e internacional, pois a qualidade profissional de seu trabalho será sempre vista como uma espécie de face externa da sociedade. A atenção também se concentra no fato de que a eficiência dos funcionários está diretamente relacionada ao nível de sua auto-organização, bem como a uma série de fatores internos. Além disso, enfatiza a importância dos funcionários públicos, bem como das pessoas que trabalham em instituições públicas e agências de proteção adequada dos direitos, liberdades e interesses legítimos de homens e cidadãos. Tal exigência para funcionários decorre das normas e princípios da legislação doméstica (incluindo a Lei Básica da Ucrânia e a Constituição da Ucrânia) e de atos e declarações legais internacionais assinados e ratificados pela Ucrânia. São oferecidas as definições de "status legal", "funcionário público", bem como "autoridade pública" do autor. Exemplos de experiências bem-sucedidas de alguns países desenvolvidos, principalmente ocidentais, na construção de tais condições para o funcionamento diário do sistema estatal e da sociedade como um todo, que conseguiram criar um status legal adequado de funcionários públicos como autoridades públicas, que atenderiam a todos os requisitos importantes atualmente.

Palavras-chave: Função pública, consolidação legislativa, regulamentação legal, status jurídico, sistema jurídico, proteção de direitos e interesses, administração pública, autoridade pública.

\section{INTRODUCTION}

Public administration is one of the most comprehensive and substantial societal subsystems. As such, it functions as an aggregate of various administrative bodies, both organized within and outside the state administration as holders of public authority, which guarantees their professional and apolitical conduct. These bodies mainly differ in organizational, financial, institutional and other features based on their dual competence of providing public services and support to citizens as parties, but also issuing authoritative individual acts/decisions in administrative procedures.'

Given the socio-political and socio-economic events that have taken place in recent years in Ukraine (gradual European integration of Ukraine and the tendency to borrow some Western legal principles and norms), and in the world at large, it should be noted that the quality of work of domestic government bodies is one of the key

1 P. KOVač. PRAVNI IN SOCIOLOŠKI VIDIKI JAVNIH POOBLASTIL [LEGAL AND SOCIOLOGICAL ASPECTS OF PUBLIC AUTHORITY]. Faculty of Public Administration. (2006).

M. Babšek, N. Tomaževič \& P. Kovač. Administrative Reforms and the Rule of Law: CaseLaw Analysis as an Inspiration for the Slovene Reorganisation of Social Work Centres. CROATIAN AND COMPARATIVE PUBLIC ADMINISTRATION 4. 2020. Pp. 595-622. 
conditions for the stability of the entire state system and the guarantor of Ukrainian sovereignty and independence.

According to the above, it is stated that for the effective and powerful, and most importantly transparent and responsible activities of all employees of the domestic state apparatus, it is necessary that they are all guided by clear and unambiguous "rules of the game", namely effective and inclusive statutes and general documents created specifically to regulate this area. At the same time, it is emphasized that in accordance with the sustainable experience of developed countries of Western Europe and North America, all of the subjects of public relations, including subjects with state power, must have a clear and well-formulated in domestic legislation legal status. This is necessary in order for each of the subjects to be absolutely protected by state laws in implementing their rights and interests, and at the same time clearly aware of the limits of their activities.

For example, in the Republic of Hungary until accession to the European Union, passive ranchise is bestowed upon only Hungarian citizens, who are of age and who reside in the territory of the Republic of Hungary. After accession to the European Union, it is bestowed upon citizens of the European Union who are of age and who reside in the territory of the Republic of Hungary. However, only Hungarian citizens may be elected to the post of mayor and to the post of the Lord Mayor of Budapest (Section 70 Subsection 2 of the Constitution). ${ }^{2}$

The issue of ethics in the activity of public administration, and thus also of local self-government administration, becomes more and more subject to legal regulations in Poland. They concern shaping of ethical behavior and fighting corruption behaviour of both representatives of local public authorities - first and foremost members of legislative bodies of local government units, which in Poland are the municipality as the basic unit, and also the county and the local-government voivodships - as well as local government employees. Such legal provisions include, for example: The prohibition of the performance of work under the employment relationship at the office of the local government unit in which the function is performed; the prohibition of performing a function of head of the organizational unit of the local government unit and its deputy; the prohibition of taking of additional activities and receiving donations that are able to undermine the confidence of voters to the exercise of the mandate; the prohibition of pursuit a business activity on their own account or jointly with other persons using the property of the local government unit, in which the function is performed; the

\footnotetext{
2 Zsolt Bártfai. COMPARATIVE STUdY ON THE LEGAL STATUS OF LOCAL REPRESENTATIVES HUNGARY. Toqueville Research Centre. Available at http://pdc.ceu.hu/archive/000 01446/01/Bartfai.pdf.
} 
prohibition of holding a specific block of shares in commercial law companies with the participation of local-government legal entities; the obligation of filing a statement on the financial position. At the same time, the current trend in Poland is to intensively develop such legal regulations. It is possible to observe the phenomenon of not only the development but also tightening of the provisions in question and tightening of sanctions resulting from them. ${ }^{3}$

\section{Methodological BASIS OF THE STUDY}

The theoretical basis of the work are the scientific works of Ukrainian and foreign scientists. A lot of scholars were engaged in the problematic and characteristic features of determining the legal status of civil servants.

In particular, the epistemological method was used to study the general preconditions, means and regularities of development of the legal status of employees as representatives of public authorities in Ukraine. The methodological basis of the work is general scientific and special methods of scientific knowledge, which are used to achieve this goal. In particular, the use of the dialectical method allowed to characterize the essence and content of basic concepts in the context of the research topic (definitions of "legal status", "civil servant", as well as "public authority"). The comparative legal method is the basis of the analysis of the legislation of Ukraine, the provisions of which determine the legal status of employees as representatives of state power. The application of the method of systematic analysis and generalization allowed to identify legislative gaps and conflicts, on the basis of which scientifically based recommendations of theoretical and applied nature were formulated. The selected methods were used in the relationship and interdependence, which ensured the comprehensiveness and objectivity of the scientific research results.

\section{RESULTS AND DISCUSSION}

\subsection{Justifying the outcomes of the findings}

In the context of consideration and study of the characteristics and issues of the legal status of civil servants as representatives of public authorities in Ukraine, it is

3 Wioleta Baranowska-Zając. LEGAL PROVISIONS OF ETHICS IN LOCAL GOVERNMENT IN POLAND - IS IT POSSIBLE TO FIGHT CORRUPTION BEHAVIOUR AMONG REPRESENTATIVES OF LOCAL AUTHORITIES BY RULES OF LAW? International Academic Conference Proceedings. (2017). Available at http://socscienceconf.com/wp-content/uploads/2017-Joint-Conference-Proceedings.pdf\#page $=80$. 
necessary, firstly, to analyze the phenomenon of the civil service itself, as well as its key elements. This is also important from the point of view of the currently prevailing human-centric legal ideology among domestic lawyers, politicians and scholars.

The above ideology is based primarily on the fact that both government officials and all other capable participants in public relations should not serve the state, religion or certain individuals, but ensure and protect the rights, freedoms and legitimate interests of each person and citizen. Despite the fact that this ideology has become dominant among the representatives of Ukrainian society only recently, it has been considered the main and most popular in progressive European countries and in the United States for a long time (and some of its elements for centuries).

The basic postulates of human-centric ideology are quite clear, transparent and easy to understand. First of all, it is noted that this ideology aims to achieve the common desire of each member of society to serve respect for the rights, freedoms and interests of everyone, including members of society, as well as their protection by the state and the public. Thus, this legal ideology defines the legal status of public authorities as one that specifies them as civil servants, and emphasizes that their main goal is to protect and properly respect the inalienable benefits of individuals.

Considering the essence and characteristics of the legal status of civil servants in terms of human-centered ideology, we can say that the content and conceptual category of such a legal phenomenon as the legal status of public administration representative are closely related to the concept and general system of civil service as such. According to the official definition provided in the Law of Ukraine "On Civil Service" of 10.12.2015 № 889-VIII, civil service is a public, professional, politically impartial activity on "practical implementation of tasks and functions of the state" regarding certain public activities. ${ }^{4}$

In particular, the above-mentioned state activity, in accordance with the above-mentioned normative legal act, includes analytical research, as well as innovative developments concerning amendments to the current legislation and search for the necessary model of development both for the country as a whole and for its individual administrative-territorial units.

This also includes the practical implementation of the way (model) of strategic development chosen by the people of Ukraine and the leadership of the state. That is, it is the direct implementation of certain plans and tasks prescribed by law, or the solution of tasks formulated by senior political figures of the state. Another equally important part of the professional activity of civil servants as representatives

4 On civil service: Law of Ukraine of 10.12.2015 № 889-VIII. Information of the Verkhovna Rada of Ukraine. 2016. № 4. Art. 43. 
of public authorities is their duty to provide a wide range of administrative services to the population of the country, as well as to supervise the effectiveness of administrative services.

In addition, another important function of employees of institutions and departments of public administration should not be overlooked. It is about the implementation by civil servants of certain managerial actions in relation to other employees, and about the implementation of some administrative actions concerning property and other material resources which belong to certain state structures.

In general, we tend to agree with the official interpretation of the concept of civil service, given in the legal act, as well as agree with the described functions that provide for the implementation of civil service. At the same time, we believe that in addition to the definition prescribed in the above law, there are certain doctrinal definitions of civil service, the legal status of civil servants and some author's classifications of the features of implementing public functions of the state.

\subsection{Analyzing the importance of acquiring a legal status}

Regarding the legal status of employees, the opinions of scholars are quite similar in substance in this area. In particular, the vast majority of scholars agree that public servants are individuals who occupy relevant public administrative positions in government agencies and departments, and carry out activities related to the provision of public administrative services to citizens of the country or perform certain managerial actions.

In our opinion, the rational point of view is expressed by the lawyer-scientist V. P. Tymoschuk, ${ }^{5}$ who points out that the so-called "foundation" of the legal status of an employee in a democratic, legal state is divided into several components. Among them, the rights and responsibilities of civil servants should be singled out as such characteristic factors that determine the principles of their activities, as well as the goals of their daily work. Along with this, there are relevant restrictions and legal regulations of the subjects of public authority, as well as factors of economic and socio-material support of the functioning of specific civil servants and entire government agencies and institutions that are in the internal hierarchical structure of the state system of the country. They determine the status and place of employees in the coordinates of the power mechanism. Thus, we agree with the thesis that all the above

5 V. P. Tymoshchuk \& A. M. Shkolyk (Eds.). PUBLIC SERVICE. FOREIGN EXPERIENCE AND PROPOSALS FOR UKRAINE. KonUS Yu. (2007). P. 541. 
components together form and consolidate in society a certain clearly defined status of civil servants as representatives of public authorities in the country.

It should be noted that any civil servant working in public bodies, in addition to his/her general, natural status of a citizen, protected by the Constitution and laws of Ukraine, also has a certain "special" status. This legal status is granted to them because they are in the civil service. Consequently, they represent not only their department, but also the state as a whole in their activity. It is erroneous to claim that a civil servant, as a representative of public authority, has a special status that can somehow raise him/her above the level of rights and freedoms of all other citizens. It is noted that on the contrary the presence of civil servants of such a special legal status increases their responsibility for their own actions and deeds, as well as makes more serious sanctions and punishments to the employees if they commit an offense or crime.

Certain changes, first of all, connected with the course of Ukraine on gradual integration into the ranks of the only developed European family, brought some reform of the legal status of civil servants in Ukraine. In particular, it was clearly stated - including in the Civil Service Development Strategy of March 18, 2015, adopted by the Cabinet of Ministers of Ukraine - that a civil servant, as a representative of public authorities, must have the necessary level of education and training, as well as transparent and politically neutral selection in order to be recruited for civil service in the institutions and departments of central executive bodies and local self-government bodies. ${ }^{6}$

Despite the fact that from 13.05.2020 this strategy lost its force, the vast majority of its initiatives were successfully implemented in the civil service. And all the requirements for civil servants and their legal status specified in this strategy have been preserved. Thus, it became an example of continuation of the pro-European orientation of power.

In the context of the above statements, it is emphasized that European integration, which has embodied in the daily life of both the state system and Ukrainian society as a whole, has made the criteria and requirements for public office quite high. According to the theses of O. I. Sushynskyi and O. V. Khudoba, not less important than the high requirements and criteria for candidates for public office are the methods

6 On approval of the strategy of reforming the civil service and service in local self-government bodies in Ukraine for the period up to 2017 and approving the plan of measures for its implementation: Resolution of the Cabinet of Ministers of Ukraine of 18.03.2015 № 227-r. Official Gazette of Ukraine. 2015. № 24. Art. 680.

7 O. I. Sushynskyi et al. PUBLIC SERVICE IN UKRAINE: THE CONCEPT AND PRACTICE OF REGIONAL PERSONNEL POLICY: SCIENT. DEVELOP. NAPA. (2013). Pp. 12-63. 
and procedures for assessing potential public officials for their compliance with such requirements.

We support this position because it is known that according to the successful practice of a number of developed countries, transparent competition for the position of civil servant, together with high, well-chosen criteria for such a position, makes competition for this position much more competitive, as well as the entire civil service. It follows logically that a more competitive but at the same time transparent working environment, based on the state public-administrative system, significantly increases the efficiency of the entire state-power mechanism of the country.

From the above, it can be stated that it is important to have a clear and unambiguous legal status of a civil servant as a representative of public authorities, which combines responsibilities for the protection of rights, freedoms and legitimate interests of citizens, and high requirements for educational level and quality of professional training of the employee. At the same time, the responsibility of each civil servant for his/her direct actions and deeds performed by him/her in the professional field should be prescribed in the legal status of the representative of public authority. The experience of developed democracies with the existing rule of law proves once again that the perspective of such an important and diverse issue as the study of the legal status of civil servants should be considered comprehensively, taking into account all components.

\subsection{The rationale and essence of selecting employees in public authorities}

In order to better understand the essence and characteristics of the legal status of employees as representatives of public authorities, it is important to understand the concept of "public service" and its fundamental comparison with the concept of "civil service". In particular, the scientific and legal community is still debating which of the two concepts is broader and can include the other in its content.

The vast majority of modern specialists in the field of jurisprudence and public administration tend to believe that the concept of "public service" is broader than "civil service". As proof of their point of view, scholars explain that the public service, as a conceptual and substantive category, includes persons in the civil service (including those in the service of central government), as well as persons who hold positions in local governments and who are still called "municipal employees".

Among other things, employees of non-governmental or non-profit foundations, institutions and organizations can be added to the category of public service 
representatives. However, according to the terminology officially accepted in the country and at the international level, we cannot call such people representatives of public authorities. But, in our opinion, such persons are subjects of public or subjects of public administration, according to other interpretation.

The issue of the definition of the legal status of employees as representatives of public authorities needs a clear distinction between the concepts of "power" and "management" or "power activities" and "management activities". For example, Y. M. Rosenfeld ${ }^{8}$ notes that power is a general status of "domination" of one subject over another, which is quite closely related to the phenomena of coercion, imperative prescriptions and the power of the state mechanism. It is emphasized that the term "power" has a meaning that is not related to the voluntary nature of relations between the subjects or any equality between them. It is worth noting that the institution of power has always had a clear hierarchical nature, and has always been supported by certain laws or traditions of the state, was binding. And its essence or structure was much more difficult to change than certain modern relations between equal subjects in areas where one of the parties carries out management activities as a service function. Unlike the government, the concept of management activity is defined by scholars as not necessarily related to the state or coercion.

On the contrary, administration may be the usual management and streamlining activities carried out by the management entity, provided that its role and status are agreed with all other persons covered by law. But at the same time, it is emphasized that non-governmental administration can also be public. To do this, it is sufficient that it is carried out by a management entity in relation to a particular institution or organization that is non-governmental but operates in the public sphere (for example, a charitable foundation). However, in this case there will be some differences in the legal status of such representatives of public administration and civil servants, as the latter are clearly related to the state of officials, and therefore, in their activities directly represent the state and its interests.

The legal status of a civil servant, as repeatedly noted by lawyers, including $\mathrm{V}$. Kuibida ${ }^{9}$ must be maintained by effective guarantees from the state regarding the unimpeded implementation of his/her activities within the limits set by law.

8 Y. M. Rosenfeld et al. PolitiCAL SCIENCE: A TEXTBOoK. Pravo. (2001). P. 2.

9 V. S. Kuibida \& V. V. Tolkovanov. EXPERIENCE OF IMPLEMENTING GOOD GOVERNANCE STANDARDS AT THE LOCAL LEVEL IN UKRAINE AND OTHER EUROPEAN COUNTRIES. Kramar Printing Center. (2010). Pp. 148-161. 


\section{CONCLUSIONS}

The issues that in one way or another are related to the content, essence and characteristics of the legal status of employees as representatives of public authorities are quite complex and multifaceted. It is emphasized that the legal status of persons who are in the civil service in the departments and institutions of central government, or who are employees of local governments, plays a significant role in the functioning of the state system of the country and consists of several elements. In particular, they include a set of rights defined by the current legislation, which are owned by civil servants, as well as their duties with respect to each other and to all other citizens.

A number of clearly defined restrictive and regulatory rules is an important factor in the structure of the legal status of public servants. As noted in the article, they are necessary because the legal status of civil servants requires clarity, absolute certainty and unambiguity in their structure and wording. This is an important factor that will successfully prevent the manifestations of various abuses by officials, their management and other legal entities.

A separate factor in the effectiveness of the day-to-day functioning of both the government mechanism as a whole and each individual employee is the level of compliance of these employees, as public authorities, with the high requirements and criteria of public administration in developed countries. These include, inter alia, the level of education of the employee and the level of his/her professional preparedness for a particular position. It is pointed out that such methods and principles of work have a positive effect on the creation of such a legal status of employees, which would interact harmoniously with all members of society.

\section{REFERENCES}

M. Babšek, N. Tomaževič \& P. Kovač. Administrative Reforms and the Rule of Law: Case-Law Analysis as an Inspiration for the Slovene Reorganisation of Social Work Centres. CROATIAN AND Comparative Public Administration 4. 2020. Pp. 595-622.

O. I. Sushynskyi et al. Public Service in Ukraine: The Concept and Practice of Regional Personnel Policy: Scient. Develop. napa. (2013).

P. Kovač. PRAVNI IN SOCIOLOŠKI VIDIKI JAVNIH POOBLASTIL [LEGAL AND SOCIOLOGICAL ASPECTS OF PUBLIC AUTHORITY]. Faculty of Public Administration. (2006). 
V. P. Tymoshchuk \& A. M. Shkolyk (Eds.). Public Service. Foreign EXPerience And Proposals for UKRAINE. KonUS Yu. (2007).

V. S. Kuibida \& V. V. Tolkovanov. Experience of Implementing Good Governance StAndARdS AT the Local LeVel IN UKRaIne ANd other European Countries. Kramar Printing Center. (2010).

Wioleta Baranowska-Zając. Legal Provisions of Ethics In LoCAL Government IN POLAND - IS IT Possible to Fight Corruption Behaviour among Representatives of Local Authorities BY RULES OF LAW? International Academic Conference Proceedings. (2017). Available at http://socscienceconf.com/wp-content/uploads/2017-Joint-Conference-Proceedings. pdf\#page $=80$.

Y. M. Rosenfeld et al. Political Science: A Textbook. Pravo. (2001).

Zsolt Bártfai. Comparative Study on the Legal Status of Local Representatives Hungary. Toqueville Research Centre. Available at http://pdc.ceu.hu/archive/00001446/01/Bartfai.pdf. 